\title{
Antinomi Diskresi dalam Bentuk Freies Ermessen untuk Penyelenggaraan Pemerintahan Berwawasan Pancasila
}

\author{
Muhammad Aziz Zaelani \\ Fakultas Hukum Universitas Sebelas Maret \\ zael.aziz@gmail.com
}

\section{Gusti Ketut Ayu Rachmi Handayani}

Fakultas Hukum Universitas Sebelas Maret ayu_igk@yahoo.com

\section{Isharyanto}

Fakultas Hukum Universitas Sebelas Maret

isharyantoisharyanto8@gmail.com

DOI : 10.23917/jjr.v9i1.8096

Submission
Track:
Received:
1 Mei 2019
Final Revision:
15 Juni 2019
Available online:
30 Juni 2019
Corresponding
Author:
Muhammad Aziz
Zaelani
zael.aziz@gmail.com

\begin{abstract}
Tujuan: Penelitian ini mempertimbangkan 3 (tiga) permasalahan, (1) diskresi memberikan kuasa besar kepada eksekutif dalam penyelenggaraan pemerintahan, (2) diskresi memberikan ruang gerak dengan limitasi minimal, (3) diskresi dalam bentuk freies ermessen, menuntut batasan dan kemungkinan tanggung gugat.
\end{abstract}

Metodologi: Penelitian ini merupakan penelitian hukum doktrinal. Sumber informasi hukum menggunakan bahan hukum primer (peraturan dan dokumen relevan) untuk selanjutnya dilakukan analisis secara kualitatif. Pendekatan konseptual, historis, dan perbandingan hukum membantu pemecahan rumusan masalah. Antinomi digunakan sebagai unit analisis terhadap diskresi dalam bentuk freies ermessen untuk menyelenggarakan pemerintahan yang berwawasan Pancasila.

Temuan: (1) diskresi sebagai kuasa eksekutif memungkinkan tuntutan pertanggungjawaban mengingat batasan Konstitusionalisme dan demokrasi; (2) dalam praktik di Indonesia, perlu optimalisasi tafsir teologis Undang-Undang Nomor 30 Tahun 2014 Tentang administrasi pemerintahan untuk mewujudkan cita keadilan dalam birokrasi sebagaimana wawasan Pancasila.

Kegunaan: diperlukan adanya mekanisme diskresi dengan segala kebebasan pemerintah berinisiatif dalam menyelesaikan permasalahan konkret yang mendesak dalam masyarakat, dengan catatan harus tetap memperhatikan batas atas dan batas bawah dalam pelaksanaannya.

Kebaruan/Orisinalitas: Model diskresi disesuaikan dengan Pancasila yang memberikan preferensi batas atas dan batas bawah berupa norma peraturan perundang-undangan.

Keywords: Diskresi, Antinomi, Pemerintahan, Pancasila 


\section{PENDAHULUAN}

Tujuan negara Indonesia dalam Pembukaan UUD RI 1945, menimbulkan konsekuensi terhadap Pemerintah untuk dapat mewujudkannya. ${ }^{1}$ Dengan cakupan tujuan nasional demikian, maka dalam literatur Indonesia dikategorikan sebagai negara kesejahteraan (welfare state). ${ }^{2}$ Sebagai negara hukum (rechtsstaat), ${ }^{3}$ Pemerintah harus berdasar pada hukum dalam melaksanakan fungsinya sebagai pemegang kekuasaan memerintah. ${ }^{4}$ Kepastian hukum menjadi hal yang wajib dipegang sebagai acuan dasarnya. Di sisi lain, keadilan dan kemanfaatan juga harus diwujudkan oleh negara untuk mencapai tujuan hukum di samping pemenuhan terhadap kepastian hukum. Oleh karena itu pemenuhan terhadap kepastian hukum, dalam praktik penyelenggaraan negara perlu diakomodasikan nilai keadilan dan kemanfaatan sehingga sejalan dengan nilai dasar hukum yang menjadi tujuan hukum itu sendiri.

Pada sisi lain, dalam praktikwelfare state, tindakan pemerintah tidak selalu harus berdasarkan asas legalitas. ${ }^{5}$ Dalam hal-hal tertentu pemerintah dapat melakukan tindakan secara bebas (diskresi) yang didasarkan pada asasfreies ermessen, yakni kewenangan yang sah untuk turut campur dalam kegiatan sosial guna melaksanakan tugas-tugas penyelenggaraan kepentingan umum. ${ }^{6}$ Diskresi hadir sebagai terobosan untuk mewujudkan

1 Untuk lebih jelasnya, maka dikutipkan bunyi Pembukaan UUD 1945 yang memuat tujuan negara itu sebagai berikut: “.....Kemudian daripada itu untuk membentuk suatu pemerintah negara Insonesia yang melindungi segenap bangsa Indonesia dan seluruh tumpah darah Indonesia dan untuk memajukan kesejahteraan umum...

2 Muchsan, Pengawasan terhadap Perbuatan Aparatur Pemerintah dan Peradilan Tata Usaha Negara, Yogyakarta : Liberty, 1992, hlm. 26.

3 Penyebutan ini pada awalnya merupakan bagian dari Penjelasan UUD 1945 sebagai salah satu diantara 7 (tujuh) kunci pokok pemerintahan pra amandemen. Namun setelah Perubahan Ketiga UUD 1945 (2001), deklarasi menjadi normatif dengan frasa sebagaimana ketentuan Pasal 1 ayat (3) UUD 1945 yang mengatakan, "Indonesia ialah negara hukum." Dalam literatur hukum tata negara, pada awalnya banyak kajian yang mencoba mendialogkan konsep negara hukum sebagai rechsstaat dalam tradisi Eropa Kontinental maupun rule of law dalam tradisi Anglo-Saxon. Dalam perkembangan yang sama, Azhary dalam disertasi Universitas Indonesia mencoba merumuskan "Negara Hukum Berdasarkan Pancasila." Namun dewasa ini istilah "negara hukum" kemudian dianggap sebagai konsep umum yang merujuk kepada tradisi pemerintahan yang lahir dari asas konstitusionalisme. Lihat: J.J. von Schimd, Ahli-Ahli Besar tentang Negara dan Hukum, terjemahan oleh R. Wiranto et.al., Jakarta : Pembangunan, 1988; Azhary, Negara Hukum Indonesia, Jakarta : UI Press; Moh. Mahfud MD, Hukum dan Pilar-Pliar Demokrasi, Yogyakarta : Gama Media, 1999; Jimly Asshiddiqie, Pokok-Pokok Hukum Tata Negara Indonesia, Jakarta : Gramedia Widiasarana, 2007; Jimly Asshiddiqie, Pengantar Hukum Tata Negara, Jakarta : Rajawali, 2010.

4 Lihat: Paulus Effendi Lotulung, Himpunan Makalah Asas-Asas Umum Pemerintahan yang Baik (AAUPB), Bandung, Citra Aditya Bakti, 1994.

5 Sjachran Basah, Eksistensi dan Tolok UKur Badan Peradilan Administrasi di Indonesia, Bandung : Alumni, 1985, hlm. 3.

6 Istilah Ermessen yang oleh beberapa penulis Indonesia diawali dengan kata sifat "freies" sesungguhnya tidak tepat. Philipus M. Hadjon mengatakan bahwa hukum administrasi Jerman "Ermessen" dan bukan 
kesejahteraan umum untuk masyarakat tanpa harus terhambat oleh keterlambatan gerak hukum dalam mengejar dinamika masyarakat. Kenyataan ini menimbulkan antinomi dalam pelaksanaan diskresi. Antinomi berpuncak pada kebebasan pemerintah dalam melakukan fungsi pemerintahan, dan pertentangannya dengan tanggung jawab dalam pelaksanaan inisiasi tersebut untuk melindungi hak-hak warga negara ${ }^{7}$ sebagaimana telah dinormakan dalam Undang-Undang Nomor 30 Tahun 2014 Tentang Administrasi Pemerintahan. ${ }^{8}$

Isu diskresi dalam perbuatan pemerintahan telah menarik minat sejumlah peneliti. Julista Mustamu dengan judul Diskresi Dan Tanggung Jawab Administrasi Pemerintahan yang dimuat dalam dalam jurnal Sasi, April-Juni $2011^{9}$, dengan hasil penelitian bagi pemerintah untuk melaksanakan pembatasan kegiatan pemerintah dalam melakukan pelayanan publik ke masyarakat. Disertasi Krishna Djaya Darumurti cenderung menguatkan pemaknaan diskresi dengan mengetengahkan asas-asas hukum yang melandasi kekuasaan diskresi pemerintah dan asas-asas hukum yang membatasi penerapan diskresi pemerintah. Frasa tersebut menimbulkan antinomi yang dikaitkan dengan hasil penelitian diatas yang saling berlawanan di satu sisi. Dengan korelasi berupa antinomi yang didapatkan dari hasil penelitian yang diuraikan diatas maka penulis berpendapat perlu menekankan antinomi tersebut sebagai suatu fokus yang dapat dibangun untuk menjawab permasalahan yang berujung kepada judul "Antinomi Diskresi Dalam Bentuk Freies Ermessen Untuk Penyelenggaraan Pemerintahan Berwawasan Pancasila”.

“freies Ermessen." Lihat: Phillipus M. Hadjon, et.al., Hukum Administrasi dan Good Governance, Jakarta, Universitas Trisakti, 2010, hlm. 24.

7 Hal ini sangat penting mengingat kewajiban utama untuk menghormati (obligationtorespect), melindungi (obligation to protect), memenuhi (obligation to fulfil) HAM setiap warga negara merupakan kewajiban negara. Dengan diratifikasinya dua kovenan turunan dari UDHR oleh Indonesia yaitu The International Covenant on Civil and Political Rights (ICCPR) 1966 dan The International Covenant on Economic, Social and Cultural Rights (ICESCR) 1966 semakin meneguhkan komitmen Indonesia dalam mewujudkan kewajiban utama di bidang HAM.

8 Peraturan perundang-undangan di Indonesia yang membahas AUPB yang berada pada rezim yang sama, yaitu UndangUndang No. 9 tahun 2004 Tentang Perubahan Atas Undang-Undang Nomor 5 Tahun 1986 Tentang Peradilan Tata Usaha Negara (UU PTUN 2004), Undang-Undang No. 28 Tahun 1999 Tentang Penyelenggaraan Negara yang Bersih dan Bebas dari Korupsi, Kolusi, dan Nepotisme (UU Anti KKN 1999), Undang-Undang No. 30 Tahun 2014 Tentang Administrasi Pemerintahan (UU AP 2014), UndangUndang No. 23 Tahun 2014 Tentang Pemerintah Daerah (UU Pemda 2014), Undang-Undang No. 25 tahun 2009 Tentang Pelayanan Publik (UU PB 2009), dan UndangUndang No. 5 Tahun 2014 Tentang Aparatur Sipil Negara (UU ASN 2014), Undang-Undang No. 37 Tahun 2008 Tentang Ombudsman Republik Indonesia (UU Ombudsman 2008).

9 Julista Mustamu, "Diskresi Dan Tanggungjawab Administrasi Pemerintahan”, Jurnal Sasi, Vol. 17 No. 2 , Bulan April-Juni 2011, hlm. 1-9. 


\section{METODOLOGI PENELITIAN}

Antinomi digunakan sebagai unit analisis terhadap diskresi dalam bentuk freiesermessen untuk menyelenggarakan pemerintahan yang berwawasan Pancasila. Penelitian ini merupakan penelitian hukum doktrinal. Sumber informasi hukum menggunakan bahan hukum primer (peraturan dan dokumen relevan) untuk selanjutnya dilakukan analisis secara kualitatif. Pendekatan konseptual membantu pemecahan rumusan masalah. Pendekatan konseptual dilakukan manakala peneliti tidak beranjak dari aturan hukum yang ada. Peneliti dalam menggunakan pendekatan konseptual perlu menggali prinsip-prinsip hukum yang dapat ditemukan dari pandangan sarjana ataupun doktrin hukum. ${ }^{10}$ Dalam pendekatan ini, konsep hukum juga dapat ditemukan dalam peraturan perundang-undangan. Namun peneliti terlebih dahulu harus memahami konsep tersebut melalui pandangan dan doktrin-doktrin yang ada.

\section{PEMBAHASAN}

\section{Antinomi Pelaksanaan Diskresi Dalam Koridor Fungsi Welfare State}

Antinomi dipahami sebagai metode-metode logis dan positif untuk menguji koeksistensi nilai yang bertujuan mencapai harmoni di dalamnya. Antinomi sudah menjadi tema di masa Yunani Kuno, menjadi sarana perdebatan panjang antar filosof pada masa itu. Hal ini sebagai sarana menguji fenomena yang terjadi terkait dalam pengujian nilai (virtue) yang umum dilakukan dalam tataran filosofis. Antinomi diartikan oleh Fockema sebagai pertentangan antara dua aturan atau lebih yang pemecahannya harus dicari dengan jalan tafsir. $^{11}$ Pada dasarnya antinomi merupakan dua hal yang saling berbeda namun saling melengkapi. ${ }^{12}$

Wolfgang Friedman berpendapat, antinomi terjadi karena berdasarkan teori, hukum berada di antara filsafat hukum dengan ilmu politik. Ini disebabkan karena pada dasarnya fungsi politik hukum adalah memilih nilai-nilai dan menerapkannya pada hukum yang dicita-citakan, sedangkan filsafat hukum merupakan perenungan dan perumusan nilai-nilai hukum. Akibatnya dari teori hukum terletak diantara filsafat hukum dengan politik hukum,

10 Peter Mahmud Marzuki, Penelitian Hukum, Edisi Pertama, Jakarta : Kencana, 2005, hlm. 138.

11 Fockema Andreae, Kamus Istilah Hukum Belanda Indonesia, Jakarta : Bina Cipta, 1983, hlm. 32.

12 Elisabeth Nurhaini Butarbutar, "Kebebasan Hakim Dalam Penemuan Hukum Dan Antinomi Dalam Penerapannya", Mimbar Hukum, Volume 23, Nomor 1, Februari 2011, hlm. 1-236. 
maka timbul persoalan-persoalan baru yang pada satu sisi berkaitan dengan filsafat dan di sisi lain berkaitan dengan politik yang saling bertentangan. ${ }^{13}$ Diskresi pada hakikatnya menampakkan suatu kecenderungan berupa pengecualian dari keharusan bertindak sesuai aturan umum (general rule) dari peraturan perundang-undangan (pendekatan rule-based atau rule following). ${ }^{14}$ Pengecualian tersebut mengandung karakter yang berhubungan erat dengan kebebasan yang disertai dengan ruang lingkup luas secara fungsional berbanding lurus terhadap cakupan dari kekuasaan/kewenangan yang dimiliki oleh badan/pejabat pemerintah. Bahkan lebih jauh lagi ada pandanggan yang beranggapan bahwa badan/pejabat pemerintah secara melekat (inheren) memiliki kebebasan bertindak residual tanpa adanya otorisasi undang-undang sekalipun. ${ }^{15}$

Krishna Djaya Darumurti menyimpulkan kekuasaan diskresi sebagai keputusan atau tindakan individual ketika pembatasan efektif pada kekuasaan pemerintah membebaskannya untuk membuat pilihan berdasarkan kemungkinan keharusan dari bertindak atau tidak bertindak demi kemaslahatan masyarakat (public good) tanpa adanya preskripsi dari peraturan perundang-undangan, dan bahkan dimungkinkan untuk menyimpang dari peraturan perundang-undangan yang berlaku. ${ }^{16}$ Dalam perkembangannya, pelaksanaan diskresi di Indonesia menimbulkan pola-pola tertentu berupa reaksi untuk melakukan pembatasan di satu sisi, dengan reaksi untuk lebih memperluas dalam melaksanakan asas freies ermessen di sisi lain. Hal ini mengandung perbedaan cara berpikir yang berujung kepada perbedaan sudut pandang yang melahirkan antinomi.

Kriteria negara kesejahteraan atau welfare state yang dianut Indonesia dapat dibuktikan dengan refleksi Pancasila yang tertuang dalam Pembukaan Undang-Undang dasar Negara Republik Indonesia Tahun 1945. Ditambah dengan tujuan untuk dapat “menciptakan kesejahteraan umum” dianggap sebagai kausa negara kesejahteraan. Negara Kesatuan Republik Indonesia juga menganut faham Negara Kesejahteraan. Hal ini ditegaskan oleh para Perintis Kemerdekaan dan para Pendiri Negara Kesatuan Republik Indonesia bahwa negara demokratis yang akan didirikan adalah "Negara Kesejahteraan" (walvaarstaat) bukan "Negara Penjaga Malam” (nachtwachterstaat). Dalam pilihan terkait

\footnotetext{
13 W. Friedman, Teori dan Filsafat Hukum Telaah Kritis Atas Teori-Teori Hukum, Terjemahan Muhammad Arifin, Jakarta, Raja Grafindo Persada, 1990, hlm. 2.

14 Krishna Djaya Darumurti, Diskresi Kajian Teori Hukum, Cetakan Pertama, Yogyakarta : Genta Publishing, 2016, hlm. 24

15 Ibid, hlm. 24.

16 Ibid, hlm. 28.
} 
konsepsi negara kesejahteraan Indonesia ini, Moh. Hatta menggunakan istilah "Negara Pengurus" 17

Indonesia merupakan negara welfare state atau social service-state, yaitu negara yang pemerintahannya bertanggung jawab penuh untuk memenuhi berbagai kebutuhan dasar sosial dan ekonomi dari setiap warga negara agar mencapai suatu standar hidup yang minimal. Dengan demikian dapat disebutkan bahwa Indonesia menganut model negara hukum welfare state minimalis. ${ }^{18}$

Konsepsi Negara kesejahteraan atau welfare state negara mengabdi sepenuhnya kepada masyarakat. Dalam negara kesejahteraan negara adalah alat satu-satunya untuk menyelenggarkan kesejahteraan rakyat. Di sini Negara aktif dalam menyelenggarakan kesejahteraan warganya untuk kepentingan seluruh rakyat dan negara. Jadi pada tipe Negara kesejahteraan ini tugas negara adalah menyelenggarakan kemakmuran semaksimal mungkin.Pengertian welfare state atau negara kesejahteraan tidak dapat dipisahkan dari konsep mengenai kesejahteraan (welfare) itu sendiri.

Merujuk pada Spicker (1995), Midgley, Tracy dan Livermore (2000), Thompson (2005), dan Suharto (2006), pengertian kesejahteraan sedikitnya mengandung 4 makna: sebagai kondisi sejahtera (well being); sebagai pelayanan sosial; sebagai tunjangan sosial; dan sebagai proses terencana yang dilakukan oleh perorangan, lembaga-lembaga sosial, masyarakat maupun badan-badan pemerintah untuk meningkatkan kualitas kehidupan melalui pemberian pelayanan sosial dan tunjangan sosial. ${ }^{19}$

Ide dasar negara kesejahteraan beranjak dari abad ke-18 ketika Jeremy Bentham (1748-1832) mempromosikan gagasan bahwa pemerintah memiliki tanggung jawab untuk menjamin the greatest happiness (atau welfare) of the greatest number of their citizens. Bentham menggunakan istilah 'utility' (kegunaan) untuk menjelaskan konsep kebahagiaan atau kesejahteraan. Berdasarkan prinsip utilitarianisme yang ia kembangkan, Bentham berpendapat bahwa sesuatu yang dapat menimbulkan kebahagiaan ekstra adalah sesuatu yang baik. Sebaliknya, sesuatu yang menimbulkan sakit adalah buruk. Menurutnya, aksiaksi pemerintah harus selalu diarahkan untuk meningkatkan kebahagian sebanyak mungkin

\footnotetext{
17 M. Yamin, Naskah Persiapan UUD 1945: Risalah Sidang BPUPKI/PPKI, Jakarta :Sekretariat Negara RI, 1959,hlm. 299.

18 Oman Sukmana, "Konsep dan Desain Negara Kesejahteraan (Welfare State)”, Sospol, Vol. 2, No. 1, JuliDesember 2016, hlm. 105.

19 Ainur Rofieq, "Pelayanan Publik Dan Welfare State", Governance, Vol. 2, No. 1, November 2011.
} 
orang. Gagasan Bentham mengenai reformasi hukum, peranan konstitusi dan penelitian sosial bagi pengembangan kebijakan sosial membuat ia dikenal sebagai "bapak negara kesejahteraan" (father of welfare states). ${ }^{20}$

Kunci pokok dalam negara kesejahteraan adalah isu mengenai jaminan kesejahteraan rakyat oleh negara. Mengenai hal ini, Jurgen Habermas berpendapat bahwa jaminan kesejahteraan seluruh rakyat merupakan hal pokok bagi negara modern. Selanjutnya menurut Habermas, jaminan kesejahteraan seluruh rakyat yang dimaksud diwujudkan dalam perlindungan atas The risk of unemployment, accident, ilness, old age, and death of thebreadwinner must be covered largely through welfare provisions of thestate. $^{21}$

Diskresi dalam kerangka pemenuhan fungsi pemerintahan dihadapkan kepada pilihan, yaitu, pertama bentuk pembatasan terhadap diskresi yang telah dinormakan dalam Pasal 24, 25, 26, 27, 28 dan 29 Undang-Undang Nomor 30 Tahun 2014 Tentang Administrasi Pemerintahan. Hal ini berdasar kepada asas kepastian hukum sebagai fungsi kontrol negara hukum terhadap pelaksanaan diskresi. ${ }^{22} \mathrm{Kedua}$, perluasan terhadap pelaksanaan diskresi dengan memahami kembali asas freies ermessen sebagai hak pemerintah dalam menggunakan inisiatifnya berupa kebebasan bertindak untuk menyelesaikan permasalahan konkret dan mendesak di dalam masyarakat. ${ }^{23}$ Bentuk antinomi ini akan diuji ketika berhadapan dengan fakta bahwa dinamika masyarakat dalam praktiknya selalu bergerak dan berubah lebih cepat dibandingkan dengan dinamika hukum. Hal ini kemudian mengisyaratkan adanya perbedaan gerak antara pembuatan undangundang dengan persoalan-persoalan yang berkembang di masyarakat.Oleh karena itu, dalam konsepsi welfare state, tindakan pemerintah tidak selalu harus berdasarkan asas legalitas. Dalam hal-hal tertentu pemerintah dapat melakukan tindakan secara bebas yang didasarkan pada asasfreies ermessen, yakni kewenangan yang sah untuk turut campur dalam kegiatan sosial guna melaksanakan tugas-tugas penyelenggaraan kepentingan umum.

20 Oman Sukmana, "Konsep dan Desain Negara Kesejahteraan (Welfare State)”, Sospol, Vol. 2, No. 1, JuliDesember 2016, hlm 105.

21 Gianfranco Poggi, The Development of the Modern State "Sosiological Introduction, California: Standford University Press, 1992, hlm. 126.

22 Yurisprudensi Mahkamah Agung yang memberikan arahan yang jelas dalam penerapan asas kepastian hukum dapat dilihat dalam Putusan MA RI No. 505 K/TUN/2012 dan Putusan MA RI No. 99/PK/2010. Hakim Agung memberikan makna bahwa asas kepastian hukum menghendaki agar Badan atau Pejabat TUN, dalam mengeluarkan KTUN, wajib mengutamakan landasan hukum yang didasari oleh kepatutan dan keadilan.

23 Lihat Ketentuan Umum Undang-Undang Nomor 30 Tahun 2014 Tentang Administrasi Pemerintahan. 
Ketika fungsi dari hukum telah terbatas akan lebih tepat jika mengakomodir diskresi di dalam menyelesaikan suatu permasalahan yang mendesak dalam masyarakat. Dalam kedudukannya sebagai asas, maka freies ermessen dapat dimaknai sebagai batu uji kritis yang penempatannya dijadikan tolok ukur pelaksanaan hukum ataupun aturan perundangundangan. Meskipun pengaturan diskresi telah dinormakan dalam dalam Pasal 1, 5, 7, 8, 9, 10, 24, 31, 39, 52, 66, dan 87 Undang-Undang Nomor 30 Tahun 2014 Tentang Administrasi Pemerintahan, yang mengedepankan kepastian hukum, namun terdapat korelasi yang tetap harus diperhatikan berupa asas freies ermessen yang menjadi dasar pelaksanaan diskresi. Artinya meskipun telah berwujud suatu norma perundang-undangan namun kedudukan asas tetap menjadi landasan yang bersifat fundamental. Asas hukum tidak selalu tertuang di dalam peraturan perundang-undangan, karena sifatnya yang abstrak. Gagasan tentang asas hukum sebagai kaidah penilaian fundamental dalam suatu sistem hukum kita temukan kembali pada karya-karya dari banyak teoretisi hukum. Paul Scholten ${ }^{24}$ misalnya, menguraikan (memberikan definisi) asas hukum sebagai berikut: "Pikiran-pikiran dasar, yang terdapat di dalam dan di belakang sistem hukum masingmasing dirumuskan dalam aturan-aturan perundang-undangan dan putusan-putusan hakim, yang berkenaan dengannya ketentuan-ketentuan dan keputusan-keputusan individual dapat dipandang sebagai penjabarannya."

Jelas dari definisi di atas, asas hukum dikatakan sebagai landasan fundamental yang abstrak dan terletak di dalam maupun di belakang sistem hukum oleh karenanya selalu berjalan beriringan dengan hukum itu sendiri. Definisi Paul Scholten juga dapat dimaknai bahwa asas-asas hukum mewujudkan sejenis sistem sendiri, yang sebagian termasuk ke dalam sistem hukum, tetapi sebagian lainnya tetap berada diluarnya. Menurut Scholten, asas-asas hukum itu berada baik di dalam sistem hukum maupun di belakangnya. Dalam hal ini pikiran Scholten terarah kepada sistem hukum positif. ${ }^{25}$

Oleh karena itu, hal ini menciptakan konklusi bahwa asas hukum tetap dipandang sebagai sesuatu yang eksis di luar norma tertulis peraturan perundang-undangan. Peranan ini berlaku juga sebagai fungsi kontrol terhadap pelaksanaan dari peraturan perundangundangan itu sendiri. Peranan ganda yang dapat dipahami dari asas hukum yang bersentuhan dengan sistem hukum positif itu berkaitan dengan sifat yang menjadi ciri dari asas hukum sebagai kaidah penilaian (waarderingsnormen). Asas hukum mengungkapkan

\footnotetext{
24 Arief Sidharta, Refleksi Tentang Hukum, Bandung : Aditya Bakti, 1995, hlm.7.

25 Ibid, hlm. 122.
} 
nilai mengenai sistem hukum karena berfungsi sebagai kaidah penilaian, tetapi asas hukum hanya sebagian saja yang dapat direalisasikan dalam hukum positif. Sejauh nilai suatu asas hukum itu diwujudkan dalam kaidah hukum dari sistem hukum positif, maka asas hukum itu berada di dalam sistem tersebut. ${ }^{26}$

Fungsi asas hukum tersebut yang utama adalah merealisasikan ukuran nilai sebanyak mungkin dalam kaidah-kaidah dari hukum positif dan penerapannya. Namun, mewujudkan ukuran nilai itu secara sepenuhnya sempurna dalam suatu sistem hukum positif adalah tidak mungkin. Asas hukum dapat berfungsi demikian karena berisi ukuran nilai. Sebagai kaidah penilaian, asas hukum dapat mewujudkan kaidah hukum tertinggi dari suatu sistem hukum positif. Itu sebabnya asas-asas hukum merupakan dan berfungsi sebagai fondasi dari sistem hukum. Asas hukum sifatnya terlalu umum untuk dapat berperan sebagai pedoman langsung bagi perbuatan tidak seperti aturan-aturan hukum, karena itu asas hukum harus dikonkretisasikan. ${ }^{27}$

Pembentuk undang-undang membentuk aturan hukum, yang di dalamnya pembentuk undang-undang merumuskan kaidah perilaku. Selanjutnya konkretisasi dalam kaidah perilaku ini terjadi melalui generalisasi putusan-putusan hakim. Jika pengkonkretisasian telah terjadi dan sudah ditetapkan (terbentuk) aturan-aturan hukum positif dan putusan-putusan; maka asas hukum tetap memiliki sifat sebagai kaidah penilaian, dengan itu maka asas hukum tampil ke permukaan. ${ }^{28}$ Ukuran nilai yang diberikan asas hukum sulit diwujudkan sepenuhnya, karena asas hukum tetap dapat berhadapan dengan sistem hukum positif dan berfungsi sebagai batu uji kritis (kritische toetssteen). Maka, setiap aturan perundang-undangan wajib menjadikan asas hukum sebagai pedoman dan di dalamnya mengejawantahkan nilai-nilai dari asas hukum tersebut. Sewaktu-waktu asas hukum dapat berfungsi sebagai batu uji terhadap aturan perundang-undangan yang tidak sesuai dengan asas hukum.

Di sisi lain pemaknaan asas freies ermessen juga perlu digali lebih lanjut karena pada dasarnya di dalam Undang-Undang Nomor 30 Tahun 2014 tersebut juga terdapat asas lain yang mendasari keberlakuan diskresi yaitu asas kepastian hukum sebagai sarana kontrol. Meskipun pemberian freies ermessen atau kewenangan bebas (discresionare power) kepada pemerintah merupakan konsekuensi logis dalam konsepsi welfare state,

\footnotetext{
26 Ibid,hlm. 122

27 Sudikno Mertokusumo, Mengenal Hukum Suatu Pengantar, Yogyakarta : Liberty, 2003, hlm. 62.

28 Arief Sidharta. Op. cit., hlm. 132.
} 
akan tetapi pemberian freies ermessen ini menimbulkan konsekuensi. Adanya kewenangan bebas ini berarti terbuka peluang penyalahgunaan wewenang (detournement de pouvoir) atau tindakan sewenang-wenang (willekeur) yang dapat merugikan warga negara. Hal ini menunjukkan bahwa kewenangan yang tidak dibatasi dan berdasarkan inisiatif cenderung akan mendorong tindakan melampaui wewenang. Maka dari itu diperlukan kontrol peradilan administrasi dengan baik.

Negara hukum adalah suatu konsep. Sebuah konsep yang bukan hanya harus dipahami, tetapi juga harus dipraktekkan dan dijalankan. ${ }^{29}$ Oleh karenanya, konsekuensi logis yang didapatkan adalah dalam mengilhami konsep negara hukum harus dipandang sebagai mekanisme kontrol bukan hanya dalam mewujudkan suatu kepastian hukum, namun disini negara hadir untuk menjamin juga kepentingan masyarakatnya. Adanya freies ermessen mempunyai konsekuensinya sendiri di bidang perundang-undangan, yakni adanya penyerahan kekuasaan legislatif kepada pemerintah sehingga dalam keadaan tertentu dan atau dalam porsi dan tingkatan tertentu pemerintah dapat mengeluarkan peraturan perundang-undangan (produk legislasi) tanpa persetujuan lebih dahulu dari parlemen.

Dalam penjelasan umum UU No. 30 Tahun 2014 lebih ditekankan bahwa segala tindakan pemerintah harus berdasar pada hukum sebagai cerminan dari ideologi Pancasila, penggunaan kekuasaan negara terhadap warga masyarakatnya bukan tanpa persyaratan, supaya tidak terjadi kesewenang-wenangan dan menegakkan prinsip-prinsip perlindungan hukum kepada masyarakat. UU No. 30 Tahun 2014 juga merupakan pengkonkretan dari Asas-Asas Umum Pemerintahan yang Baik (AUPB) ${ }^{30}$ yang ditransformasikan ke dalam norma hukum yang mengikat dan menjadi dasar hukum dalam penyelenggaraan pemerintahan di dalam upaya meningkatkan kepemerintahan yang baik (good governance).

Sejarah perkembangan AUPB di Indonesia dapat dilihat dari perkembangan prinsip AUPB dalam berbagai peraturan perundang-undangan, praktik penerapan AUPB dalam putusan pengadilan atau yurisprudensi serta doktrin. Perkembangan AUPB dari prinsip yang tidak tertulis bergeser menjadi norma hukum tertulis berlangsung cukup lambat. Sejak UU PTUN 1986, AUPB tidak diatur secara eksplisit. Pasal 53 ayat (2) UU PTUN

29 Yovita. A. Mangesti dan Bernard L. Tanya, Moralitas Hukum, Yogyakarta : Genta Publishing, 2014, hlm. 86.

30 AUPB merupakan terjemahan dari 'Algemene Beginselen van Behoorlijk Bestuur' (ABBB), sebuah istilah dalam Bahasa Belanda. Di Inggris, prinsip ini dikenal sebagai 'The Principal of Natural Justice' atau 'The General Principles of Good Administration', sementara di Perancis diistilahkan sebagai 'Les Principaux Generaux du Droit Coutumier Publique' dan di Belgia disebut sebagai 'Algemene Rechtsbeginselen', serta di Jerman dinamakan 'Allgemeine Grundsätze der Ordnungsgemäßen Verwaltung'. 
1986 tidak secara eksplisit menyebut AUPB sebagai dasar pengajuan gugatan Keputusan TUN. Kemudian, AUPB diatur dalam Pasal 53 Ayat (1) dan (2), serta dalam Penjelasan Pasal 53 Ayat (1) dan (2), UU PTUN 2004. Pasal 53 Ayat (1) pada dasarnya menekankan hak gugat perorangan dan badan hukum melalui Peradilan TUN, manakala haknya dirugikan oleh penyelenggara Negara. Sedangkan Pasal 53 ayat (2) menekankan bahwa selain pelanggaran terhadap UU tertulis, pelanggaran terhadap AUPB juga dapat dijadikan dasar untuk mengajukan gugatan kepada penyelenggara Negara.

\section{Model Diskresi Berwawasan Pancasila}

Pancasila sebagai dasar negara, secara normatif harus menjadi fundamen atau dasar penyelenggaraan Pemerintahan Republik Indonesia. Kedudukan Pancasila mempunyai konsekuensi bahwa segala kegiatan Penyelenggaraan Pemerintahan harus berdasar pada Pancasila secara materiil maupun etik. Pancasila memiliki padanan atau cerminan dari jiwa dan cita-cita hukum bangsa Indonesia yang merupakan norma dasar dalam penyelenggaraan bernegara dan yang menjadi sumber dari segala sumber hukum sekaligus sebagai cita hukum (rechtsidee), baik tertulis maupun tidak tertulis di Indonesia. Cita hukum inilah yang mengarahkan hukum pada cita-cita bersama bangsa Indonesia. Cita-cita ini secara langsung merupakan cerminan kesamaan-kesamaan kepentingan diantara sesama warga bangsa. ${ }^{31}$

Pancasila dalam kedudukannya juga sebagai norma dasar yang dalam kedudukannya ini menjadi norma dasar bagi tata hukum Indonesia. ${ }^{32}$ Pemaknaan seperti ini diidentikkan dengan istilah Hans Kelsen yaitu Grundnorm. Terdefinisi menjadi dua unsur, yaitu "posisi Grundnorm" dan "peran Grundnorm". ${ }^{33}$ Mengenai posisi Grundnorm, Kelsen mendudukan norma dasar tersebut sebagai premis awal. Grundnorm diasumsikan sebagai dasar dimana segala sesuatunya dimulai, tidak diturunkan dari manapun, validitasnya juga diterima begitu saja. It is valid because it presupposed to be valid. ${ }^{34}$ Grundnorm merupakan dasar

\footnotetext{
31 Isharyanto, Teori HukumSuatu Pengantar Dengan Pendekatan Tematik, Cetakan I, Surakarta : WR, 2016, hlm. 156.

32 Bernard L. Tanya dan Theodorus Yosef Parera, Samuel F. Lena, Pancasila Bingkai Hukum Indonesia, Cetakan Pertama, Yogyakarta : Genta Publishing, 2014, hlm. 13.

33 Ibid, hlm. 13.

34 Hans Kelsen, General Theory of Law and State, New York : Russel \& Russel, 1961, hlm. 116.
} 
tanpa harus disesuaikan dengan norma yang lain. Oleh karenan itu, Grundnorm melampaui tata hukum positif yang bersifat trasendental-logic yang berada di atas hukum positif. ${ }^{35}$

Model diskresi yang berwawasan Pancasila diharapkan dapat memberikan sebuah referensi mengenai kebebasan berdasarkan inisiatif pemerintah dalam melakukan tindakan menghadapi permasalahan mendesak dalam masyarakat. Tindakan itu harus merefleksikan nilai-nilai Pancasila. Dalam hal ini implikasinya adalah Grundnorm berupa Pancasila menjalankan peran sebagai batu uji validitas tata hukum positif.

Sejatinya Pancasila sebagai landasan bernegara baik secara subtantif maupun moril memberikan gambaran berupa batas-batas yang dijadikan rujukan dalam menjaga penyelenggaraan pemerintahan tetap berada di jalurnya. Batas tersebut adalah batas atas dan batas bawah. Dalam hal ini batas atas dimaksudkan untuk lebih memaknai hakikat Pancasila sebagai landasan moril dan bernegara. Landasan moril yang dimaksud adalah pengejawantahan dari sila Ketuhanan Yang Maha Esa dengan analogi pelaksana diskresi harus menitik beratkan tanggungjawab moril kepada Tuhan Yang Maha Esa. Hukum pada dasarnya mempunyai hubungan dengan moralitas, sebagaimana pendapat Hart yang merefleksikan pengaruh moralitas terhadap hukum (the influence of morality on Law). Hukum pada setiap negara modern menunjukkan ribuan poin penuh moralitas yang diterima oleh masyarakat maupun ide-ide moral yang lebih luas. Pengaruh ini kemudian merasuki hukum secara nyata. Banyak hal yang menunjukkan bagaimana hukum mencerminkan moralitas. Hal demikian adalah fakta, yang berarti stabilitas sistem hukum tergantung sebagian pada bentuk kesesuaiannya dengan moral dan keberadaannya harus diakui. $^{36}$

Sejalan dengan hal tersebut, hukum harus dipandu oleh moralitas, kaitannya dengan pelaksanaan diskresi, ditujukan untuk dapat menciptakan diskresi yang mempunyai sumbu moralitas sebagai panduannya. Dengan kata lain, moral menjadi koridor penuntun hukum yang diimplementasikan oleh subyek hukum. Moral menjadi penuntun manusia dalam setiap kegiatan hidupnya, yang memberikan kepada kebenaran menurut rasio. Aristoteles menjabarkan inti manusia adalah moral yang rasional, yang memandang kebenaran (theoria, kontemplasi) sebagai keutamaan hidup (summum bonum). ${ }^{37}$

\footnotetext{
35 Bernard L. Tanya dan Theodorus. Op. Cit., hlm. 13.

36 M. Ali. Safa'at, Konsep Hukum H.L.A Hart, Jakarta: Konstitusi Press, 2016.

37 Bernard. L. Tanya, Penegakkan Hukum dalam terang Etika, Yogyakarta: Genta Publishing, 2011.
} 
Refleksi berikutnya, diskresi harus mampu mengejawantahkan nilai kemanusiaan yang adil dan beradab. Keadilan sebagaimana menjadi inti dari rasa kemanusiaan yang beradab tersebut, memberikan tolok ukur yang harus dicapai oleh pembuat diskresi. Maka diskresi yang dihasilkan harus memenuhi rasa keadilan yang sejatinya ditujukan kepada rakyat. Keadilan itu sendiri menyiratkan beberapa makna. Gustav Radbruch mempunyai isian yang paling menarik mengenai definisinya dikaitkan dengan peran keadilan, yaitu ditempatkan sebagai cita hukum (Rechtsidee), yang mempunyai posisi sama dengan Grundnorm uraian Kelsen yang sama-sama mengandaikan adanya norma atau nilai yang melampaui dan berada diatas tata hukum positif. Bedanya disini, Rechtsidee sudah ditentukan isinya secara limitatif, yaitu memajukan kebaikan hidup manusia yang menjadi ukuran bagi adil atau tidak adilnya suatu tata hukum. ${ }^{38}$

Sila Kemanusiaan yang Adil dan Beradab, juga menuangkan penekanan mengenai harkat dan martabat manusia. Manusia diciptakan oleh Tuhan Yang Maha Esa dengan seperangkat hak yang menjamin derajatnya sebagai manusia yang terangkum dalam Hak Asasi Manusia. Dalam hal ini kedudukan sebagai negara hukum (rechtstaat) diakui sebagai kerangka pengatur untuk menjamin hak asasi manusia berupa menjamin kepentingan keadilan bagi semua orang. Setiap orang berhak mendapatkan hak keadilannya. Dengan demikian negara hukum yang dikembangkan bukanlah absoluterechtsstaat melainkan democratischerechtsstaat. ${ }^{39}$ Diskresi diharapkan mampu membuka ruang untuk menyelesaikan persoalan mendesak dalam masyarakat dengan tetap menjunjung tinggi Hak Asasi Manusia sebagai bentuk pengakuan terhadap harkat dan martabat manusia dalam lingkup Kemanusiaan yang Adil dan Beradab.

Diskresi juga harus merefleksikan nilai persatuan dan kesatuan. Dalam paradigma ini maka diskresi tetap harus berpedoman terhadap kepentingan umum. Seperti halnya dalam kaidah pembuatan aturan maka tidak boleh bertentangan degan kepentingan umum, tidak berlawanan dengan norma dalam masyarakat, sehingga dapat menciptakan aturan yang mempunyai daya laku dan memiliki legitimasi berupa pengakuan dari masyarakat itu sendiri.

Nilai demokrasi yang tertuang dalam sila Kerakyatan yang Dipimpin oleh Hikmat Kebijaksanaan Dalam Permusyawaratan Perwakilan. Demokrasi yang dianut di Indonesia

\footnotetext{
38 Bernard L. Tanya dan Theodorus. Op. Cit., hlm. 15.

39 Mohamad Sinal, Pancasila Konsesnsus Bangsa-Bangsa Indonesia, Malang : Madani, 2017, hlm. 104.
} 
adalah demokrasi yang berdasarkan Pancasila. Dengan demikian demikrasi Indonesia mengandung arti disamping nilai umum dituntut nilai khusus. Demokrasi Indonesia adalah kerakyatan yang dipimpin oleh hikmat kebijaksanaan dalam permusyawaratan perwakilan. Dalam hal ini pemerintahan harus memegang teguh konsepsi dari rakyat, oleh rakyat dan untuk rakyat. ${ }^{40}$ Diskresi sebagai bentuk inisiatif pemerintah dalam menjalankan fungsinya harus dapat menjelma sebagai penguat demokrasi berbasis kerakyatan ini.

Terakhir sebagai tujuan maka diskresi harus memenuhi tujuan berupa keadilan sosial bagi seluruh rakyat Indonesia. Keadilan yang dimaksud disini adalah secara masif yang berupa keadilan sosial. Perlu dimaknai hal ini dekat kaitannya dengan konsepsi welfare state yang menjadikan kesejahteraan rakyat sebagai tujuan utama. Beranjak dari refleksi Pancasila yang tertuang dalam Pembukaan Undang-Undang dasar Negara Republik Indonesia Tahun 1945. Ditambah dengan tujuan untuk dapat "menciptakan kesejahteraan umum" dianggap sebagai kausa negara kesejahteraan. Hal ini sudah cukup mendeskripsikan kewajiban pemerintah dalam mencapai kesejahteraan berupa Keadilan Sosial Bagi Seluruh Rakyat Indonesia. Maka diskresi harus sejalan dengan pengkonkritisasian nilai ini yang mana dalam perjalanannya diskresi diharapkan hadir dan mampu menjadi sarana ringkas dan ideal pemerintah dalam mengatasi permasalahan dalam mencapai tujuan negara tersebut.

Setelah melakukan telaah terhadap nilai-nilai Pancasila sebagai batas atas pelaksanaan diskresi, maka selanjutnya dapat dilakukan analisis terhadap batas bawah pelaksanaan diskresi. Batas bawah yang dimaksud tentu saja adalah norma peraturan perundang-undangan yang telah diwujudkan dalam Undang-Undang Nomor 30 Tahun 2014 Tentang Administrasi Pemerintahan. Berangkat dari asas kepastian hukum dan budaya positivisme hukum, maka keberadaan dari suatu norma tertulis menjadi eksistensi dari hukum itu sendiri. Maka menjadi kewajiban dari negara hukum sebagaimana ciri yang diutarakan oleh Julius Stahl ${ }^{41}$ yaitu, (i) Pemisahan Kekuasaan, (ii) Pemerintahan berdasarkan undang-undang, (iii) Menjamin Hak Asasi Manusia, dan (iv) Peradilan Administrasi yang terpisah. Hal ini membuktikan urgensi dari peraturan perundang-

\footnotetext{
40 Komitmen ini merupakan esensi yang paling umum dijumpai dalam mendiskusikan pengertian dan kaidah demokrasi. Dengan demikian, ia mengisyaratkan adanya pengakuan bahwa dalam demokrasi maka kedaulatan tertinggi adalah di tangan rakyat. Esensi demikian, di samping merupakan makna filosofis Pancasila, juga bagian dari kaidah Pasal 1 ayat (2) Undang-Undang Dasar Negara Republik Indonesia Tahun 1945.

41 Anwar. C, Teori Dan Hukum Konstitusi, Malang : Setara Press, 2011, hlm. 47-48.
} 
undangan menempati koridor yang harus dipenuhi sebuah negara hukum dalam perjalanannya.

Namun memaknai sebuah hukum perlu ditafsirkan bahwa sejatinya peraturan perundang-undangan bukanlah menjadi poin vital. Keberadaannya bukanlah merupakan suatu obyek utama. Peraturan perundang-undangan dalam hal ini lebih tepat ditempatkan sebagai sarana untuk obyek yang dimaksud. Oleh karenannya tetap diperlukan adanya mekanisme diskresi dengan segala kebebasan pemerintah berinisiatif dalam menyelesaikan permasalahan konkret yang mendesak dalam masyarakat, dengan catatan harus tetap memperhatikan batas atas dan batas bawah dalam pelaksanaannya. Itulah model pelaksanaan diskresi berwawasan Pancasila yang dicita-citakan oleh penulis.

Jika divisualisasikan, maka model pelaksanaan diskresi berwawasan Pancasila dapat digambarkan sebagai berikut:

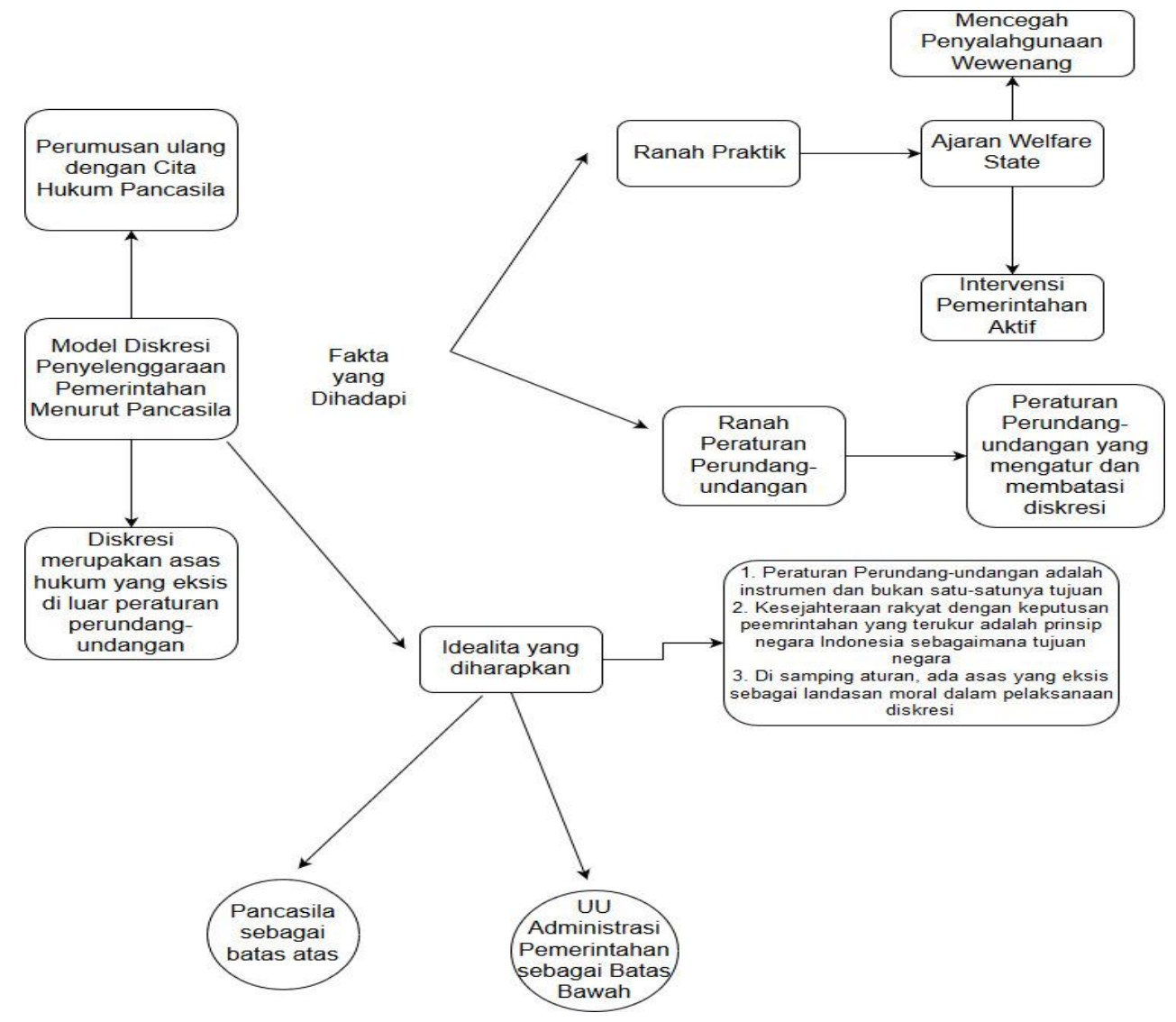

\section{PENUTUP}

Mengetengahkan bahwa pelaksanaan diskresi mempunyai dua sumbu yang melahirkan antinomi. Pertama, bentuk pembatasan terhadap diskresi yang telah dinormakan dalam Undang- 
Undang Nomor 30 Tahun 2014 Tentang Administrasi Pemerintahan. Hal ini berdasar kepada asas kepastian hukum sebagai fungsi kontrol negara hukum terhadap pelaksanaan diskresi. Kedua, perluasan terhadap pelaksanaan diskresi dengan memahami kembali asas freies ermessen sebagai hak pemerintah dalam menggunakan inisiatifnya berupa kebebasan bertindak untuk menyelesaikan permasalahan konkret dan mendesak di dalam masyarakat.Model diskresi disesuaikan dengan Pancasila yang memberikan preferensi batas atas dan batas bawah berupa norma peraturan perundang-undangan.

\section{REFERENCES}

Andreae, Fockema, Kamus Istilah Hukum Belanda Indonesia, Jakarta : Bina Cipta, 1983.

Anwar. C, Teori Dan Hukum Konstitusi, Malang : Setara Press, 2011.

Asshiddiqie, Jimly, Pengantar Hukum Tata Negara, Jakarta : Rajawali, 2010.

Asshiddiqie, Jimly, Pokok-Pokok HUkum Tata Negara Indonesia, Jakarta : Gramedia Widiasarana, 2007.

Azhary, Negara Hukum Indonesia, Jakarta : UI Press.

Basah, Sjachran, Eksistensi dan Tolok UKur Badan Peradilan Administrasi di Indonesia, Bandung : Alumni, 1985.

Butarbutar, Elisabeth Nurhaini, "Kebebasan Hakim Dalam Penemuan Hukum Dan Antinomi Dalam Penerapannya", Mimbar Hukum, Volume 23, Nomor 1, Februari 2011, hlm. $1-236$.

Darumurti, Krishna Djaya, Diskresi Kajian Teori Hukum, Cetakan Pertama, Yogyakarta : Genta Publishing, 2016.

Friedman, Wolfgang, Teori dan Filsafat Hukum Telaah Kritis Atas Teori-Teori Hukum, Terjemahan Muhammad Arifin, Jakarta, Raja Grafindo Persada, 1990.

Isharyanto, Teori HukumSuatu Pengantar Dengan Pendekatan Tematik, Cetakan I, Surakarta : WR, 2016.

Hadjon, Phillipus M, et.al., Hukum Administrasi dan Good Governance, Jakarta, Universitas Trisakti, 2010.

Kelsen, Hans, General Theory of Law and State, New York : Russel \& Russel, 1961.

Kertonegoro, Sentanoe, Jaminan Sosial dan Pelaksanaannya di Indonesia, Jakarta : Mutiara Sumber Widya, 1987.

Lotulung, Paulus Effendi, Himpunan Makalah Asas-Asas Umum Pemerintahan yang Baik (AAUPB), Bandung, Citra Aditya Bakti, 1994. 
Mahfud MD, Moh, Hukum dan Pilar-Pliar Demokrasi, Yogyakarta : Gama Media, 1999.

Mangesti, Yovita A dan Bernard L. Tanya, Moralitas Hukum, Yogyakarta : Genta Publishing, 2014.

Marzuki, Peter Mahmud, Penelitian Hukum, Edisi Pertama, Jakarta : Kencana, 2005.

Mertokusumo, Sudikno, Mengenal Hukum Suatu Pengantar, Yogyakarta : Liberty, 2003.

Muchsan, Pengawasan terhadap Perbuatan Aparatur Pemerintah dan Peradilan Tata Usaha Negara, Yogyakarta : Liberty, 1992.

Mustamu, Julista, "Diskresi Dan Tanggungjawab Administrasi Pemerintahan", Jurnal Sasi, Vol. 17 No. 2, Bulan April-Juni 2011, hlm. 1-9.

Poggi, Gianfranco, The Development of the Modern State "Sosiological Introduction, California: Standford University Press, 1992.

Rofieq, Ainur, "Pelayanan Publik Dan Welfare State", Governance, Vol. 2, No. 1, November 2011.

Safa'at, M. Ali, Konsep Hukum H.L.A Hart, Jakarta: Konstitusi Press, 2016.

Schimd, J.J von, Ahli-Ahli Besar tentang Negara dan Hukum, terjemahan oleh R. Wiranto et.al., Jakarta : Pembangunan, 1988.

Sidharta, Arief, Refleksi Tentang Hukum, Bandung : Aditya Bakti, 1995.

Sinal, Mohamad, Pancasila Konsesnsus Bangsa-Bangsa Indonesia, Malang : Madani, 2017.

Sukmana, Oman, “Konsep dan Desain Negara Kesejahteraan (Welfare State)”, Sospol, Vol. 2, No. 1, Juli-Desember 2016, hlm 105.

Tanya, Bernard L., Theodorus Yosef Parera dan Samuel F. Lena, Pancasila Bingkai Hukum Indonesia, Cetakan Pertama, Yogyakarta : Genta Publishing, 2014.

Tanya, Bernard L, Penegakkan Hukum dalam terang Etika, Yogyakarta: Genta Publishing, 2011.

Yamin, Muhammad, Naskah Persiapan UUD 1945: Risalah Sidang BPUPKI/PPKI, Jakarta :Sekretariat Negara RI, 1959. 